Anna Maria Karczewska

10.15290/cr.2016.14.3.03

University of Białystok

\title{
The Mirabal sisters and their testimonio in Julia Alvarez's In the Time of the Butterflies
}

\begin{abstract}
The Mirabal sisters opposed the regime of Rafael Trujillo, a notorious Dominican dictator who terrorized the nation for almost 30 years. Their brutal deaths on the dictator's order served as a catalyst for change. The sisters became heroines and martyrs in the fight against Trujillo's repressive regime, and symbols of both popular and feminist resistance. Julia Alvarez's novel tells the Mirabal story and describes their legacy. The aim of the paper is to demonstrate how In the Time of the Butterflies gives access to Dominican history, and how literature creates a voice for victims of political violence and terror.
\end{abstract}

Keywords: Rafael Trujillo, dictatorship, the Dominican Republic, Julia Alvarez, the Mirabal sisters.

I myself invent time by first conjuring up the

voices and spirits of the women living under brutal repressive regimes ... [b]ecause I want to do justice to their voices. To tell these women, in my own gentle way, that I will fight for them, that they provide me with my own source of humanity.

Helena María Viramontes

The official website of the United Nations informs us that through the resolution of 17 December 1999, the United Nations General Assembly designated 25 November as the International Day for the Elimination of Violence against Women to raise public awareness of the problem. This date came from the brutal assassination of three sisters, Patria, Maria Teresa and Minerva Mirabal ("International Day for the Elimination of Violence against Women"). They were political activists from the Dominican Republic, who were labelled with the underground code name Las Mariposas (Eng. Butterflies), and who were killed on the orders of the notorious Dominican dictator Rafael Leonidas Trujillo. The Mirabal sisters inspired resistance cells throughout the country, and their brutal deaths on the dictator's order served as a catalyst for change. The sisters became heroines 
and martyrs in the fight against Trujillo's repressive regime, and symbols of both popular and feminist resistance.

The Dominican American writer, Julia Alvarez, in her collection of essays entitled Something To Declare (1998) describes her fascination with the story of the Dominican heroines as her life parallels that of the Butterflies. Alvarez's father had been part of the same revolutionary underground movement and was involved in the plot to overthrow the dictator. For this reason the family was forced to flee to the United States, and Alvarez explains the situation:

[a]nd so it was that my family's emigration to the United States started at the very time their lives ended. These three brave sisters and their husbands stood in stark contrast to the self-saving actions of my own family and of other Dominican exiles. Because of this, the Mirabal sisters haunted me. Indeed, they haunted the whole country. $(1998,198)$

The writer was haunted by the story since she was ten. However, it was not until 1986 that she became personally involved. In 1992 Alvarez met Dedé Mirabal, a fourth sister who survived, and this encounter resulted in a book (Alvarez 1998, 198, 202) that was nominated for the $1995 \mathrm{Na}$ tional Book Critics Award (Fregoso, 8).

Alvarez's novel tells the Mirabal story and describes their legacy through the lens of fiction. The aim of the paper is to demonstrate how In the Time of the Butterflies (1995) gives access to Dominican history and memory, how it creates a voice for victims of terror, and lets them be heard on their own terms.

The story of In the Time of the Butterflies unfolds against a background of The Era of Trujillo (1930-1961), which was characterized by totalitarian rule, terror, torture and assassinations. With the dictator's predatory regime, his personality cult, deification and mandatory parades in honor of El Jefe, Trujillo's image was inscribed upon every aspect of Dominican society. The successful Cuban revolution and Fidel Castro's coming to power in 1959 played a major role in radicalizing many Dominicans, including the Mirabal sisters. They took part in clandestine activities organized by the anti-Trujillo Movimiento Revolucionario 14 de Junio (MR1J4). This was a leftist underground revolutionary movement whose leader was Manolo Tavarez, Minerva's husband. Members of The 14th of June Movement tried to assassinate the dictator in 1960, but their efforts were defeated by Trujillo's army, which resulted in the imprisonment and torture of the three sisters and their husbands, among others. The sisters were soon released from prison, but Trujillo was alleged to have given orders to kill them. The Mirabal sisters were assassinated on their way back from prison, where they visited their incarcerated husbands on November 25, 1960 (Peguero, 182). To hide the nature of the crime, their bodies and that of their driver, Rufino de la Cruz, were placed in their own jeep, which was pushed over a cliff near Santiago. Their deaths were reported in the press as an automobile accident. However, Dominican people were not fooled by the story. The murder of the sisters planted the seed of rebellion among the Dominican population and served as a catalyst for overthrowing Trujillo. Although many factors were at play in Trujillo's downfall, Bernard Diederich credits the 
murders with providing the motivation to end the tyrannical dictatorship, and claims that "the cowardly killing of three beautiful women in such a manner had greater effect on Dominicans than most of Trujillo's other crimes. ... It did something to their machismo. They could never forgive Trujillo this crime" (Diederich, 72). After their deaths and in the years to follow the Mirabal sisters became hallowed icons for the Dominican Republic, and they were transformed into symbols of martyrdom, feminist icons and revolutionary heroines. Monuments stand in their honor in many Dominican towns. The whole country bears commemorative markers in the form of street names, schools or murals. Their family home in the province of Salcedo was converted into a museum. Gradually, their fame spread internationally, and not only with the help of Alvarez, whose book was adapted into a movie of the same title starring Salma Hayek. In 2010, Juan Delancer directed Trópico de Sangre, a film drama based on the true story of the historic Mirabal sisters. The Dominican heroines are also present in two highly acclaimed novels: The Feast of the Goat (2000) by Mario Vargas Llosa, and The Brief Wondrous Life of Oscar Wao (2007) by Junot Díaz, who writes:

\footnotetext{
The Mirabal Sisters were the Great Martyrs of that period. Patria Mercedes, Minerva Argentina, and Antonia María-three beautiful sisters from Salcedo who resisted Trujillo and were murdered for it. ... Their murders and the subsequent public outcry are believed by many to have signaled the official beginning of the end of the Trujillato, the "tipping point," when folks finally decided enough was enough. (83)
}

Alvarez's In the Time of the Butterflies is categorized by different critics as a historical novel, a dictator novel, fictionalized biography, historiographic metafiction, or hagiographic commemorafiction. I propose to read Alvarez's novel as testimonio, a relatively new genre in Latin American literature. George Yúdice defines it as "an authentic narrative, told by a witness who is moved to narrate by the urgency of a situation (e.g. war, oppression, revolution, etc.)" (17). He also explains: "... the testimonialista gives his or her personal testimony "directly," addressing a specific interlocutor" (15). According to Yúdice, in testimonio "truth is summoned in the cause of denouncing a present situation of exploitation and oppression or in exorcising and setting aright official history" (17). In the case of In the Time of the Butterflies the surviving Dedé tells the story of her sisters' lives, and their active opposition and resistance to the notorious regime of Rafael Trujillo. She tells her story to a gringa dominicana, who is the author's alter ego. The author's interest in Las Mariposas triggers Dedé's memories, and through her recollections the reader travels back into the past to learn the story of Patria, Minerva and María Teresa.

Testimonio, as a genre, is notoriously fluid and difficult to categorize, because the word "testimonio" can describe anything written by a first-person witness who wishes to tell her/his story of trauma. John Beverley, an expert on testimonial literature, defines it as

a novel or novella-length narrative in book or pamphlet (that is, printed as opposed to acoustic) form, told in the first person by a narrator who is also the real protagonist or witness of the events he or she recounts, and whose unit of narration is usually a life or a significant life experience. (31) 
Linda J. Craft adds to this definition additional characteristics. She claims that a testimonio may include all categories considered conventional literature, such as autobiography, autobiographical novel, oral history, memoir, confession, diary, interview, eyewitness report, life history, novellatestimonio, nonfiction novel, or "factographic" literature (22). The definition of testimonio of the Cuban cultural center Casa de las Américas reads:

Testimonios must document some aspect of Latin American or Caribbean reality from a direct source.

A direct source is understood as knowledge of the facts by the author or his or her compilation of narratives or evidence obtained from the individuals involved or qualified witnesses. (quoted in Beverley, 103)

Because in many cases the witness is someone illiterate, or if literate, not a professional writer, the production of a testimonio generally involves the tape-recording and then the transcription and editing of an oral account by an interlocutor who is an intellectual, often a journalist or a writer. Yúdice and Beverley, however, insist on the nonliterary purity of the testimonio. Unfortunately, this idea "shrinks the parameters of the genre considerably, for not many narrative texts - as Hayden White and others have made clear - evade the effects of the literary" (Emery, 17). What is more, the definition offered by the Casa de las Américas asserts that "literary quality is also indispensable" (in Beverley, 103). Moreover, "what we encounter in testimonial narrative is not the Real as such ... but rather a "reality effect" created by the peculiar mechanisms and conventions of the text, which include a textual simulacrum" (a literary simulacrum of oral narrative) (Beverley, 2). By the same token Alvarez affirms that the sisters whose life and death she described are neither the Mirabals of fact nor the Mirabals of legend. They are the Mirabals of her creation to show their humanity, which was removed in the process of acquiring legendary status. Alvarez worried that by becoming too iconic they would be robbed "of the dignity of being real human beings" (Rosario-Sievert, 35). The writer wanted to show that Las Mariposas were flesh and blood, real-life women, imperfect as people are, with all their fears, insecurities, marital strife and other human flaws, to create a connection between them and the reader. This "readerly intimacy" is required here as the role of testimonio is to place the reader under an obligation to respond: "... we may act or not on that obligation, we may resent or welcome it, but we cannot ignore it. Something is asked of us by testimonio" (Beverley, 1). Testimonio asks for solidarity with liberation movements and human rights struggles; it involves a political response from the audience.

Reading Rigoberta Menchú's controversial testimonio, one also realizes that the genre is intended to represent "the reality of a whole people" (Menchú, 1), which is also affirmed by Domitila Barrios in her testimonio entitled Let Me Speak! Testimony of Domitila, A Woman of the Bolivian Mines (1977):

I don't want the story that I am about to tell to be interpreted as a personal matter. Because I think that my life is related to my people. What has happened to me might have happened to hundreds of others in my 
country.... That's why I say that I do not want to simply tell a personal story, I want to speak of my people. I want to bear witness to all the experience that we have gained through so many years of struggle. (13)

Although Alvarez pays tribute to only three women, the rest of the victims are evoked in the pages of her book because the events she describes changed the course of the lives of a large segment of the population, and they constitute a shared sense of anxiety and fear, the collective memory $^{8}$ of the Dominican Republic. Those historic memories are fixed events that affected the lives of virtually all members of Dominican society. Alon Confino defined collective memory much more broadly, as "the representation of the past and the making of it into shared cultural knowledge by successive generations in books, films, museums, commemorations, and others" (1386). Through the prism of these multiple 'sites of memory' (Pierre Nora's phrase) people negotiate the past. Therefore, the memories of the individual became merged, and submerged, within group, or collective, memory.

The narrative frame of the novel is constructed via conversations between Dedé and the gringa dominicana. The novel spans the period from 1938-1994, although the major part of the story takes place during the brutal regime of Rafael Trujillo. The novel is divided into three parts, with chapters narrated by the Mirabal sisters. The dead sisters speak in the first person, and the plot is chronological. It covers the sisters' family life, schooling, political awakening, their activities in opposition, and finally their death. The book amalgamates the voices to give a multiperspective picture of life under Trujillo's dictatorship.

The story unfolds during the brutal regime of Trujillo, against a background of persecution and oppression. As young girls, at the Inmaculada Concepción boarding school, the sisters experience eye opening events connected with the injustices rampant in their country and the evils of Trujillo. One of Minerva's friends, Sinita, tells her a story of how Trujillo killed the members of her family. At first, Minerva could not believe her words in the face of the process of the deification of the dictator and overwhelming propaganda:

"Bad things?" I interrupted. "Trujillo was doing bad things?" It was as if I had just heard Jesus had slapped a baby or Our Blessed Mother had not conceived Him the immaculate conception way. "That can't be true", I said, but in my heart, I felt a china-crack of doubt. ... The country people around the farm say that until the nail is hit, it doesn't believe in the hammer. Everything Sinita said I filed away as a terrible mistake that wouldn't happen again. Then the hammer came down hard right in our school, right on Lina Lovatón's head. (Alvarez 1995, 17, 20)

\footnotetext{
8 'Despite widespread use of the term 'collective memory', it is only fair to point out that many historians are very uneasy about the concept. A number explicitly substitute parallel or alternative terms that better reflect their understanding of the processes through which particular groups, communities or nations collectively remember their past. These terms include, for example, 'collective remembrance,' 'collected memories,' 'cultural memory,' 'public memory,' or 'mnemonic communities"” (Green 37).
} 
It became clear for Minerva that Trujillo exercised his masculine entitlement ruthlessly, seducing young women. The story of Lina Lovatón is an example of the abuse and sexual harassment that were used as a psychological instrument of torture by the Trujillo regime against women and their families, such as the Mirabals. It indicates machismo as the necessary underpinning for the Latin American dictatorship. Trujillo's appetite for young women was legendary. Dominican families used to hide their daughters when Trujillo visited their areas. Trujillo's statutory rape of fourteen-year-old Lina Lovatón happened with the nuns' tacit blessing, and it was a revealing experience for Minerva Mirabal. This experience coincides with the beginning of her first menstrual cycle, and both are understood as a loss of innocence and the onset of problems in her life, since the nuns at school use a euphemism for menstruation and call it complications: "I lifted the covers, and for a moment, I couldn't make sense of the dark stains on the bottom sheet. Then I brought up my hand from checking myself. Sure enough, my complications had started" (Alvarez 1995, 20). With the awakening of Minerva's political conscience come problems, not only hers, but also her whole family's. Minerva is the driving force behind her family's activism. However, all the sisters sooner or later come to painful awareness of the cruelties and injustices in their country and realize that its citizens live in terror of their own government (Sirias, 55-56). When they get more deeply involved in the underground movement it leads to the imprisonment of Minerva, Mate, Patria and their husbands, and other resistance leaders and sympathizers.

Although the dominant theme of Alvarez's book is the cruelty of the dictator, his pathological thirst for revenge and adulation, Trujillo's appearances are brief and infrequent. The notorious dictator appears in the book as a theme rather than a character, but his ominous shadow dominates every aspect of Dominican society in such a way that he becomes a leitmotiv and omnipresent obsession. His authoritarianism, immorality and wickedness are compared to the patriarchal society. The Mirabal father embodies male privilege in Latin American families, and maintains and reinforces gender hierarchies, refusing to allow Minerva to attend the university or see boyfriends. In Paulo Freire's words he becomes "sub oppressor" (45) and such sub oppressors supported Trujillo and kept him in power. When the sisters discover their father's double life with a mistress and four other illegitimate daughters, they begin to question everything they hold sacred. For Minerva, her beloved father matches the dictator on the scale of hypocrisy. Hence their rebellion is not only against the dictator, but also against machismo and patriarchy. They contest their subaltern condition by actively joining the resistance and by denouncing male chauvinism. The second pillar of women's oppression in provincial Dominican society appears to be Catholicism. It helps maintain the socially prescribed roles of mothers and wives. It plays a central role in the formation of gender roles, norms and expectations in the male-controlled totalitarian regime, where girls are prepared for motherhood and marriage instead of university studies (Fregoso, 10-11).

In her novel Alvarez presents the everyday lives of the sisters, with all their joys and problems, in order not to make them exotic or turn them into a myth, and also to validate the feminist motto: "The personal is political." The motto underscores the connections between personal experience and larger social and political structures (López-Calvo, 95). Alvarez wanted to show the 
real spirit of the sisters. "I wanted to understand the living, breathing women who had faced all the difficult challenges and choices of those terrible years. I believe that only by making them real, alive, could I make them mean anything to the rest of us" (Alvarez 1998, 203). The author honors their lives with all their quirks and weaknesses, because, as she notes, "they have been so wrapped in superlatives and ascended into myth that they have become inaccessible and unknown to us" (Alvarez 1995, 342). Furthermore, she adds that deifications of all kind are dangerous, because behind them is the same god-making impulse that created Trujillo the tyrant (Alvarez 1995, 324). She wished to humanize The Butterflies as "becoming too iconic would rob them of the dignity of being real human beings and the dignity of what that sacrifice means" (Sievert, 35). In doing so, Alvarez allows the reader the luxury of personal contact with each of the sisters, and this in turn involves some kind of reaction, a political response so demanded by testimonio. "The book incites us to go beyond the text, to raise more questions and to search for more answers" (McCallum, 114). Moreover, Alvarez recovers women's personal voices, desires and ambitions, and "feeds the need to know the dead, and even to be voyeuristically close to the moment of their death" (Socolovsky, 8).

Alvarez, by giving voice to female characters, gives voice in literature to the previously voiceless, and she replaces the traditionally male history with a feminine one, bringing Latin American women "into history as agents, out from under the shadows of ... men" (Behar, 6). In the same spirit Hélène Cixous maintains that

woman must write her self: must write about women and bring women to writing, from which they have been driven away as violently as from their bodies - for the same reasons, by the same law, with the same fatal goal. Woman must put herself into the text - as into the world and into history - by her own movement. (309)

Stavans, in his review, also praises Alvarez for representing the Mirabals' political struggle as "an attack against phallocentrism as an accepted way of life in Hispanic societies" (554). Moreover, In the Time of the Butterflies refuses to construct Latinas only as victims of male oppression or objects of patriarchy. The book refuses to accept the traditional perception of Latin American women as politically passive and socially marginalized, voiceless and submissive (Bados Ciria, 311).

Although the three brave subversive wives were crushed by the phallocentric regime, they record a posthumous victory, and since then these sisters, "who fought one tyrant, have served as models for women fighting against injustices of all kinds" (Alvarez 1995, 342).

The story of the Mirabal sisters presented in the form of a novel has a particular significance for a nation which was never able to confront the crimes of its own past in the aftermath of Trujillismo. The written story of the Mirabal sisters to a certain extent symbolizes a substitute for the truth and justice that was never granted to the victims. Their history is symbolic of a tragedy, which Valerio Holguín calls "el trauma histórico del Trujillato" (Holguín, 92), which belongs not just to the Mirabal family but also to all Dominicans. Alvarez's sonnet suggests that the trauma of the Dominican past has yet to be claimed, owned, and fully acknowledged: "In my own D.R. we 
have many rains: /the sprinkle, the shower, the hurricane, / the tears, the many tears for our many dead" (Alvarez 1996, 25).

The events that change the course of lives of whole populations are at first characterized by a high level of talking. Later, monuments are built and movies are made at predictable times after the upheavals occur. Testimonios are also such monuments, which aid memory, help to keep collective memories alive to organize and assimilate the event in people's minds and allow the society to move past the experience (Pennebaker et al., viii).

By writing in English Alvarez makes this fragment of Dominican history accessible to a wider audience, a public far greater outside Latin America (Craft, 3). Once testimonio reaches the international community, it provides evidence for human rights offences, as well as causes for action. Beverley supports this point in his book on testimonio, positing that testimonial novels are used primarily "as a way of mobilizing international opinion in favor of an end to the violence" (84). Testimonio deliberately blurs the line between "the personal and the political" to give the women (and men) on the margins a voice. The testimonial novel is a forum of participation for all underprivileged peoples to have the power of the written word. Such stories create a representative voice for victims of political violence and psychological terror who have been silenced. They seem necessary for the process of reburial and grieving, and they can promote healing and solidarity among disaffected groups and expand human capacity for empathy (Mullins, 4-12). Testimonios are texts that cross borders and bring the subjugated knowledge of people's history and their memory into the consciousness of mainstream readers.

\section{References:}

Alvarez, Julia. 1998. "Chasing the Butterflies." Something to Declare. Chapel Hill: Algonquin Books of Chapel Hill, 197-209.

Barrios de Chunagara, Domitila and Moema Viezzed. 1977. Let Me Speak! Testimony of Domitila, A Woman of the Bolivian Mines. New York: Monthly Review Press.

Beverley, John. 2004. Testimonio. On the Politics of Truth. Minneapolis: University of Minnesota Press.

Ciria, Concepción Bados. 1997. "In the Time of the Butterflies by Julia Alvarez: History, Fiction, Testimonio and the Dominican Republic." Monographic Review: Revista Monografica 13, 406-416.

Cixous, Hélène. 1986. “The Laugh of the Medusa.” Critical Theory since 1965. Ed. Hazard Adams and Leroy Searle. Tallahassee: Florida State University Press, 309-320.

Emery, Amy Fass. 1996. The Anthropological Imagination in Latin American Literature. Columbia: University of Missouri Press.

Fregoso, Rosa Linda. 2003. "Julia Alvarez, In the Time of the Butterflies." Reading U.S. Latina Writers Remapping American Literature. Ed. Alvina E. Quintana. New York: Palgrave Macmillan, 7-14. 
Green, Anna. 2004. "Society Individual Remembering and 'Collective Memory': Theoretical Presuppositions and Contemporary Debates." Oral History 32.2, Memory and Society (Autumn), 35-44.

Holguín, F. Valerio. 1998. "En el tiempo de las mariposas de Julia Álvarez: una reinterpretación de la historia." Chasqui: revista de literatura latinoamericana, Mayo 27.1, 90-115.

"International Day for the Elimination of Violence against Women 25 November." United Nations. 8 May 2017 www.un.org/en/events/endviolenceday/background.shtml

Lopez-Calvo, Ignacio. 2005. God and Trujillo. Literary and Cultural Representations of the Dominican Dictator. Gainesville: University Press of Florida.

Pennebaker, James W., Dario Paez and Bernard Rime. 1997. Collective Memory of Political Events: Social Psychological Perspectives. New Jersey: Lawrence Erlbaum Associates.

Rosario Sievert, Heather. 1997. "Conversations with Julia Alvarez." Review: Latin American Literature and Arts 54, 31-37.

Sandoval, Anna. 1999. "Building up Our Resistance: Chicanas in Academia." Frontiers: Journal of Women Studies 86, (quoting Helena María Viramontes), 86-92.

Socolovsky, Maya. 2006. "Patriotism, Nationalism, and the Fiction of History in Julia Alvarez's In the Times of the Butterflies and In the Name of Salome." Latin American Literary Review 34.68 (Jul-Dec.), 5-24.

Stavans, Ilan. 1994. "Las Mariposas." The Nation 7 Nov. 1994, 552-556.

Yúdice, George. 1991. “Testimonio and Postmodernism.” Latin American Perspectives 18.3.

Special Issue: Voices of the Voiceless in Testimonial Literature. Ed. Georg M. Gugelberger and Michael Kearney, 15-31. 